\title{
Sustaining Local Communities through Cultural Industries Based on Local Wisdom in Tigawasa Village
}

\author{
Agung Parameswara ${ }^{1} \&$ Athina Wulandari ${ }^{1}$ \\ ${ }^{1}$ Faculty of Economy and Business, Warmadewa University, Bali, Indonesia \\ Correspondence: Agung Parameswara, Faculty of Economy and Business, Warmadewa University, Bali, \\ Indonesia. Jln. Terompong. E-mail: agungparameswara@warmadewa.ac.id
}

Received: July 26, 2020

doi:10.5539/jsd.v13n6p139
Accepted: November 22, 2020

Online Published: November 24, 2020

URL: https://doi.org/10.5539/jsd.v13n6p139

\begin{abstract}
Globalization with the presence of information technology and development is a challenge for the sustainability of local communities that identic with tradition and culture. The value of local wisdom is an identity that is a strength because there is no in other places. This study wants to prove that local wisdom can provide added value and could even be used as a fundamental factor for sustainable development. The subject of study is the cultural industries. It is said, cultural industries that have cultural values are an important component and it contains the strength of narration of the output. The investigation is carried out by exploring local wisdom-based economic activities, access to labor, and social sustainability to show that the value of local wisdom as an identity can realize a sustainable economy in a rural area. In-depth interviews and observations with an ethnography approach to the case study method conducted in Tigawasa Village, Buleleng. This village is Bali Aga Village, home of Bali Mula or Bali's original people, the earliest inhabitants of the island, which have local wisdom of bamboo.
\end{abstract}

Keywords: local wisdom, cultural industries, bamboo, bali, sustainable development

\section{Introduction}

The recent of sustainability issue of local communities whereas the backbone of their economic and social activities depends on landscapes and local knowledge is threatened by the phenomenon of globalization. Areas that are close to the center of the economy and tourism are developing rapidly, but other areas far from the center are still underdeveloped and tend to have rapid urbanization rates (Suntajaya, 2016). This wave of globalization experienced a spectacular leap that affected the lives of every individual, society and nation (M. Baiquni, 2017). The threaten began with the slow fade of the value of local wisdom. In fact, local wisdom is an important capital that is a driving force in the process of economic development ( $\mathrm{Li} \& \mathrm{Li}, 2011)$. UNESCO (2005) mentions that nowday creative cultural economic activities as an important component of a knowledge-based economy in postmodern industry. This sector it's not only think of taking into account higher growth and creation of jobs that are higher than average, but this sector is also a strategy for communities empowerment and strategy to preserve local values. In Indonesia Fahmi (2016) found in Bali, the location of traditional cultural industries 75 percent are located in rural areas. The result is contrast from the most of studies which demonstrate that the location of the cultural industries mostly concentrated in urban areas of developed countries. The economic accounts of the traditional people are based on the potential of the site they occupy. Traditional people should deal with limitations of the area in fulfilling their daily life. The relationship between the people and the nature is intimate where the human beings respected nature.

The island of Bali, which is very well known as a world tourist destination, unwittingly has the potential to be developed into sustaining the local communities in rural areas to support the cultural industries. The beauty of nature, the diversity of cultural arts, creativity and ideas possessed by the Balinese people make it a great capital to develop the cultural industries. The cultural industries in the certains methods are preserved by generation to generation. Further, the main sources of inspiration and idea to developing the cultural goods is based on local knowledge. Although new designs and creativities are applied on the product, the characteristic of these industries is prioritise to preserve the values that provide it's value as the unique selling points (Lily Kong, Gibson, Khoo, \& Semple, 2006; O'Connor \& Xin, 2006). This sector is one of the alternatives to the island's main sector, tourism, to support sustainable economic growth and local development. By paying attention to the values of culture and local wisdom, it is expected to be able to make a significant contribution as an effort to community welfare. 
Considering the role of culture in sustainable development has been intens topic among the scholars (Soini \& Birkeland, 2014). Hawkes (2001) introduced cultural sustainability and explained culture as a fouth pilar of sustainability as it importance of culture in human development. Throsby (2001) assessing the topic of cultural economic point of view and explaining the cultural economy to the principle of sustainability and discussed Sustainability Concepts in Indigenous and Non-Indigenous Cultures (Throsby \& Petetskaya, 2016). Cochrane (2006) Exploring cultural capital and its importance in sustainable development. Whereas Soini \& Dessein (2016) introduced aproaches and eight structuring dimensions for exploring the culture-sustainability relations. Komariah (2016) explored the local wisdom of traditional village to sustaining and managing environmental sustainability. In the other hands, Sandoval-Rivera (2020) has found the collective value and community solidarity as a role in local culture and cultural practice from local community present the creation of sustainable indigenous knowledge. The relationship between cultural economic activities and local wisdom to sustaining local communities take our focus to investigating, given that most of the focus of research locations on the cultural industries that mentioned to Fahmi (2016) is in urban areas. On the other hand, the many cultural industries in the village need more an attention to explore. This paper aims to explore economic potentials of traditional villages and societies in Bali in order to develop strategies to sustain and regenerate the communities in the global era. Firstly, a preliminary research has been carried out in Tigawasa Village in North Bali. This research seeks a detailed characteristics and problems faced by traditional communities in relation to globalization in terms of their economic sustainability.

\subsection{Culture and Sustainability}

Duxbury \& Jeannotte (2011) explained that the discourses of the position culture on "culture and sustainability" related to local or urban development, there are four main conceptual threads emerged. First, culture as a capital. Second, culture as process and way of life. Third, culture as a central bidning element providing the values undelying sustainable (or unsustainable) actions. Fourth, culture as a creative expression which providing insights on sustainability concerns. They added one approaches to conceptualizing culture as process and way of life. Culture, in a broader sense, must be seen as an epistemic framework not only as an additional pillar of sustainable development after the environment, economy, and social because of people's identity. Culture has shaped how human behavior acts, (Nurse, 2006).

There are many definitions of culture. According to Throsby (1995) the interpretation of culture is an activity carried out in art that covers a broader aspect called the culture industry. The culture industry is an industry that has culture as the core of industrial activities such as those involving artistic. He explained culture in a specific meaning in representing the cultural sector in the economy. Meanwhile, culture in anthropological interpretation is a set of attitudes, practices, beliefs owned by the community expressed in the values and customs of certain societies that go through the stages of evolution from time to time, which pass down from one generation to the next generation. Spencer-oatey (2012) underlines the main characteristics of culture. culture is manifested in various deep layers, culture also influences behavior and interprets human behavior, culture can be distinguished from universal human nature and unique individual personalities, culture is linked to community groups and influences biological processes, culture is a social and individual construction, distributed culture through social groups psychologically, so that describing culture will always be fuzzy because culture has elements that have both universal (etic) and distinctive (emic) elements, culture is learned, Culture is subject to gradual change..

The definition of sustainability can be interpreted as the capacity to maintain and increase the availability of materials or desired conditions that are long-term oriented. according to Harrington (2016) the definition of sustainability is a long-term oriented concept to keeping and maintaining the conditions and material objects. Furthermore he add that sustainability can be considered as a broader concept than sustainable development and not only focuses on human well-being based on what interpretation of Word Commision of Environment and Development. The Brundtland Report defines sustainable development as follows: "Sustainable development is development that meets the needs of the present without compromising the ability of future generations to meet their own needs." Based on the Brundtland Commission, it is broadly agreed that sustainability consists of three pillars: ecological, economic and social. However, in recent years, more voices have asserted that sustainability also involve the cultural dimension, (Gartler, Kuklina, \& Schweitzer, 2020). Throsby (2017) proposed the concept of culturally sustainable development. Soini \& Dessein (2016) proposed three roles of culture in sustainable development. Culture for, in, and as sustainability.

\subsection{Cultural Industries to Traditional Cultural Industries}

The cultural sector according to Nurse (2006), plays a important role for the formation of identity and also industry in the economic sector with both national and regional growth potential. Garham on (UNESCO Statistics, 2009) explained that cultural industries as a descriptive meaning, referring to the industry "in our society that uses the 
mode of product characteristics and the organization of industrial companies to produce and spread symbols in the form of goods and services that have cultural values as commodities". Furthermore, O'Connor (1998) and A. C. Pratt (1997) on (UNESCO Statistics, 2009) define the cultural industry by linking the sociology of art and economics. These operative definitions highlight sectoral relations the importance of creating new contents in the process of production as a basis for creating the value, and also the creative content on its product has economic potensial value.

Industry (activity) culture (sector) from definition it is a sector that produces goods and services that are often associated with value, culture and entertaiment (Caves, 2003) which main purpose is the creation and communication of symbolic meaning (D Hesmondhalgh, 2007). In the other hand, Throsby (2008b) states in further definitions of cultural goods and services can also be proposed which derive from the consideration of the types of values they manifest or produce, i.e. it can be suggested that they produce cultural values in addition to whatever commercial values they may have in them, and that these cultural values may not be fully measured in economic terms (monetary). In other argument, cultural goods and services are being valued by those who make and come them for any reason such as social and cultural purpose.

In addition, in UNESCO's view, the term "cultural industries" is a series of activities that produce and distribute cultural goods or services, which at that time are considered as certain attributes, uses or purposes, manifesting or conveying cultural expressions regardless of possible commercial values they have. One of the most significant contributions from UNESCO is how a series of UNESCO reports illustrates how the transformation towards the relationship between culture and economy by making important contributions to a better understanding of the role of the cultural industry in new cultural policies and economic realities. UNESCO seeks to bring culture from the periphery of development to central places (UNESCO Statistics, 2009). For the government as a policy maker, it is important to be able to take steps to integrate the concept of the culture industry in the development strategy and to ensure that, it is necessary to recognize the economic potential of the culture industry itself.

According to UNESCO Statistics (2009) the classification of the culture industry is another problem that needs to be addressed. The lack of a strong theoretical definition has led to misunderstanding and confusing situations regarding the structural elements of this industry, although certain progress has been made in developing a general analytical framework. In this case, several authors made significant contributions in modeling the cultural and creative industries. The basic dimension of this approach is related to the structure of traditional art, based on criteria taken from aesthetic theory, a broader perspective adds several criteria from the field of industry such as the degree of industrialization of the production process (David Hesmondhalgh, 2008) or the level of cultural and economic value (Throsby, 2008a, 2008b).

Throsby (2008c) proposes and discusses the "concentric circle model" whose base on the concept that the cultural industries have economics and cultural value and from different layers of cultural content relative to the commercial value. In the culture industries, the relationship between cultural and economic values appears in the form of concentric circles, the main thing is that the core concentric circle is in the middle as the core and while at the distance from the core to the periphery, the circle shows the degree to which cultural content decreases relative. to its commercial value. The basic model consists of four circles: Core creative arts (visual arts, music, performing arts), other core cultural industries (photography, film, museums, galleries, libraries), wider cultural industries (publishing and printing, sound recording, television and radion, heritage, computing and video games) and related industries (advertising, architecture, design, fashion) (Throsby, 2008b; UNESCO Statistics, 2009). Furthermore, Hesmondhalgh on UNESCO explained that the structure of the culture industry includes the core industry and the peripheral industry. Core industry is directly involved in the process of production of social meaning and using industry average of production and distribution content. Peripheral industry is involved in text production that use semi-industrial and non industrial methods for reproduction of symbols (UNESCO Statistics, 2009).

In Indonesia, Fahmi (2016) make a classification in accordance with the characteristics of the creative and cultural industries in Indonesia. He started by including the advertising, architecture, design, publishing, IT and software, radio and television sub-sectors, and research and development can be categorized as creative industries because, in general, this sub-sector utilizes individual creativity to provide services, often created specifically, for consumers whose preferences must be handled. In this case, research and development, as well as technology, are generally needed to produce innovative ideas or designs. As such, the product has the potential to be protected by copyright. We also include visual arts, recordings, and performances in this category of creative industries because, in general, this subsector relies heavily on new ideas to express their art, even though they are 'traditional' and do not always use new hardware technology.

Furthermore, Fahmi (2016) argued that traditional crafts have different characteristics and this seems incompatible 
with the conceptual definition of the creative industry. He believes that the traditional craft sector might use new technology to support its production process, but certain methods or habits are maintained. For an example in the batik and weaving industry, these two industries have the values of identity, culture, meaning and tradition that are inherent in each of these products both from their use and from their design. Beyond that, traditional crafts are naturally inherent in the traditions which are the main source of product ideas in this sector. This kind of craft has been around for a long time and has become an inseparable part of the communal participatory place-identity of all these craft activities and the most important of them is the existing knowledge and values passed down from generation to generation. In the cultural industries, new ideas and creativities are applied on it's cultural goods and services, the core prerequisite is the preservation of identity value and heritage (Fahmi, 2016; Gibson \& Kong, 2005; Jean-Paul Bourdier \& Nezar AlSayyad, 1989; Maha Putra, 2017; O’Connor \& Xin, 2006; Poespowardjo, 1986; Throsby, 2001).

From the characteristic of cultural industries whereas keep of it's the traditional way of production, meanings and cultural values as commercial values, in the other hands the knowledge passed down from generation to generation inherent in cultural goods, besides explaining the concept of cultural industries from "western" concept as explained in the literature to see distribution in the regional area which is usually associated with functions the city as a center of cultural consumption such as staging art or drama, visual art, literature (Buitrago Restrepo, Pedro Felipe; Duque Márquez, 2012; Fahmi, 2016; Pratt \& Jeffcutt, 2009; Scott, 1999; Throsby, 2008a, 2008b; UNESCO Statistics, 2009).

\section{Method}

This study is using qualitative method with case study approach because is relevant to explore a traditional cultural industries based on local knowledge that passed down from generation to generation in local communities. In order to do so, Tigawasa Village, in Buleleng Bali, Indonesia, an ancient village home of Bali Mula or Bali's original, the earliest inhabitants of the island selected as the case for this study. the Tigawasa village has an area of $1690 \mathrm{Ha}$ where according to data from the village has a population of 6101 people with $50.76 \%$ male and $49.24 \%$ female. The investigation begins with exploring the components that build economic activities based on the village identity as bamboo craftsmenship. Furthermore, the workers involved, social sustainability and how the components are formed can be developed into a cultural economic model based on local wisdom values. Data collection through unstructured interviews with local people and visual etnography using photography approaches to find the relationship between economic activity and their local knowledge with natural setting of research location. Furthermore, because the value of local wisdom is carried out by people, we also conduct in-depth interviews to appreciate the voices of people to look at their ways in perform local economy activity.

\section{Results}

Tigawasa Village is one of the Desa Tua - old indigenous villages in Buleleng, Bali, apart from the villages of Sidatapa, Cempaga, Tigawasa and Pedawa (SCTP) that live in mountainous areas. The people of Bali Tua, are a group of people who inhabit the mountains and are a difficult society to be subdued when the Majapahit Kingdom controls Bali. The life of Balinese Aga people is dependent on nature, such as; land, water, and forest, as the roots of economic activity based on their local wisdom. This situation reflects that the economic environment is a strong reason for the people of Bali Tua to use resources in producing goods to fills up their needs of life.

Local genius is all forms of knowledge, beliefs, understanding or insight as well as customs or ethics that guide human behavior in life in the ecological community. Keraf (2002) state that local wisdom it's not only concern the knowledge and understanding of people about humans and how good relations between humans are, but also concerns the knowledge, understanding and customs of humans, nature and how the relationships among the inhabitants of this ecological community must be established. Local genius is actually a part of ethics and morality that help people to answer the moral question of what to do, how to act specifically in the field of environmental and natural resource management. Ethics, which means "customs" or "habits", is a good living habits, good living procedures, both in a person or in a group of people. These good living habits are followed and passed down from one generation to another and are standardized in the form of rules, rules, norms that are disseminated, known, understood and taught in society. The belief that is practiced by the community becomes a local culture where the values and behavior of the people in interacting with the environment in which they live are carried out wisely. This indicates that local community activities refer to the values and capacities of nature.

Local genius is a value and a character for the local community that has been followed as an identity. Local genius as a knowledge that is used as the basis for all actions of community groups that have been carried out from generation to generation to live and meet the needs of the challenges of modernization. The value of local genius becomes the basis for the community to live and utilize natural and human resources in all social and economic 
and cultural activities so that it can be enjoyed by the next generation. Local genius is a principle that is adopted into a belief in its interaction with the environment which can be seen from how the local community transforms it into a system of institutionalized customary norms. This principle came from the knowledge and experiences of local communities which are accumulated into values and characters that found in each local community group.

Balinese society has a culture that is essentially based on values that are based on the philosophical teachings of the life of an agrarian society. Balinese culture upholds the values of balance and harmonization of the relationship between humans and god (parahyangan), fellow human relations (pawongan), and human relations with the environment (palemahan). This philosophy is believed to be the three causes of well-being in life called the Tri Hita Karana philosophy. Originally Tri Hita Karana is only a theological and sociocultural teaching originated from Balinese scriptures. The harmonious and balance relationship between three aspect has to be maintained to reach happienes and well-being to Balinese society. The concept consists of spatial conceptions, physical and spiritual relation between humankind and the nature. Along with the rise of sustainability issues, values that exists in the concept of Tri Hita Karana, are considered relevant to the environmental and socio-economic-cultural development (Budarma \& Suarta, 2017).

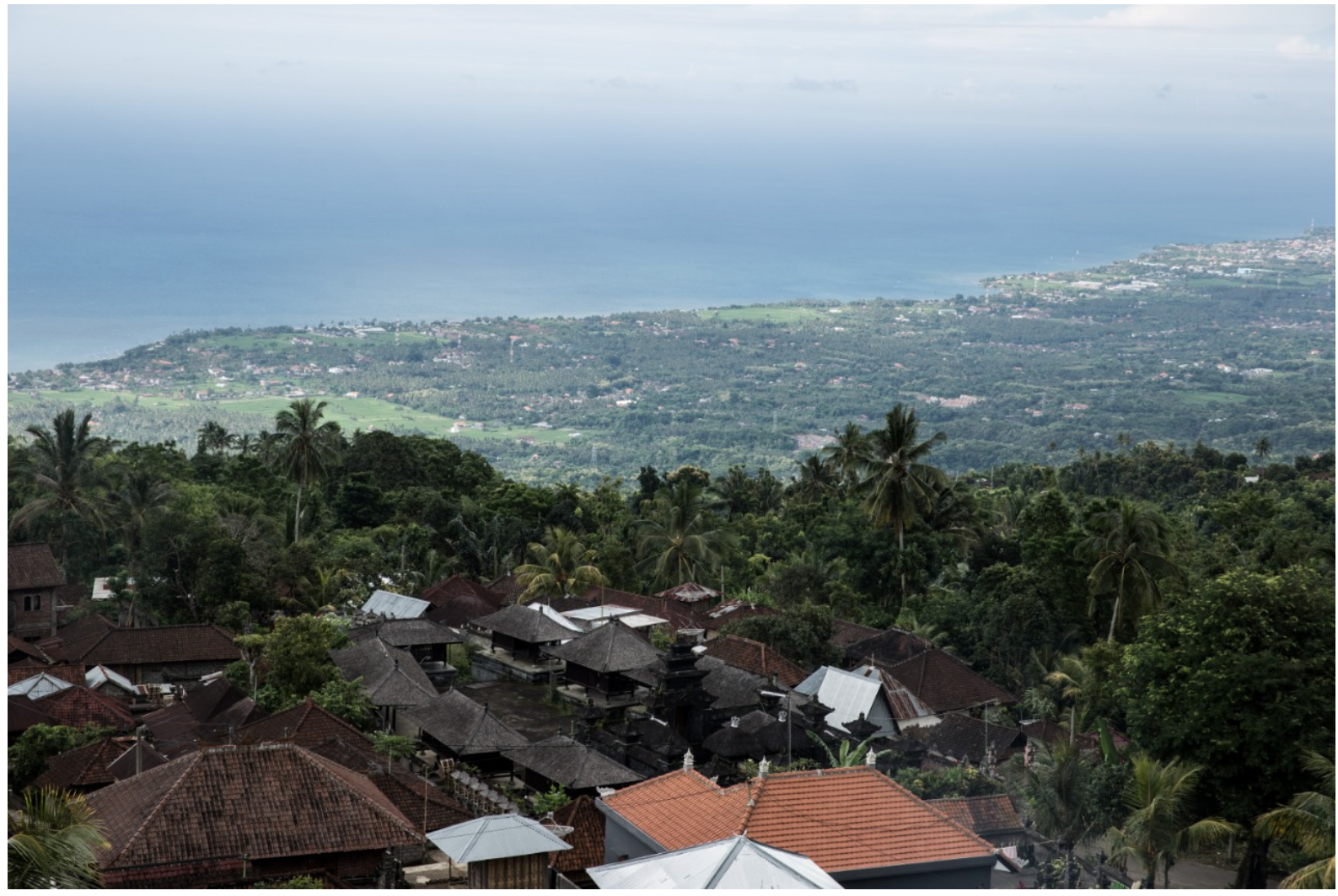

Figure 1. The village of Tigawasa is seen from above. Tigawasa village is one of the ancient village of Bali Aga which the indigenous people of Bali live in the village. The characteristic of the Bali Aga is the community lives in the mountainous area and depend on their natural resources and surroundings

The socio-cultural life of the Tigawasa community has been fused with bamboo for centuries, (Arinasa, 2005). From sociocultural aspect of Tigawasa Village, bamboo is part of local communities live and culture. Almost the entires home of villagers maintains land plots or hours of yard for bamboo plants. Related to the economic activities of local communities, One of the craftswomen mentioned "[...] At first, local people only weaved bamboo walls for the daily needs of the people in the village. Houses in the surrounding villages use bamboo walls, especially in the kitchen area. However, since 1975, the idea emerged to make bamboo baskets for religious ceremonies.... [..]. After nearly 4 decades, the activity of making bamboo baskets from the village of Tigawasa has become the identity of the villagers. This is in line with the busy ritual and religious activities of the Balinese people so that the demand for bamboo baskets is never empty. Religious activities in Bali make the cultural industry alive and thriving. In this sense, the economy is embedded in culture. This phenomenon has been explained by Klamer (2017) in his book Doing the Right Thing about ordinary business carried out by humans such as trade, consumption, work as 
part of cultural phenomena. In the record interview, weaving bamboo is integral with Tigawasa community live's. Interviewees also remarked that people in the village 80 percent of 4,368 villagers work as woven bamboo weaving named Keben. He mentioned that "[...] bamboo is the life support of our village community... [..]" (Komang Edi jayantika, Head of Administrative community as a subdivision of a village in Umasendi hamlet).

Since 1975 there has been a development of colorful motives. While Bali's Hindu ceremonies continue to use keben, the motifs of the baskets are now varied, ranging from butterflies, batik, roses, nagasari to lettering. We found that 80 percent of the making of bamboo basket locally called keben is created by women villagers, while the men do work looking for bamboo and finishing process. Bamboo is the means of support for our village people. Bamboo craftsmanship has also been handed down through generations. The knowledge of weavingthat handsdowns from generations to generation in the village of Tigawasa became an economic activity and the economic potential in the village and also the area of neighbourhout. Local economic activity as an identity and is continuously carried out as a source of livelihood for the local community and even helps the local community's economy to provide labor opportunities and sustainable.

Arinasa (2005) argue that the local community in Tigawasa Village almost all has their own land, both in the yard and in "tegalan" (garden) planted with bamboo. about 63\% (12 species) bamboo is considered original because it has been owned since the ancestors inhabited this village before the reign of Majapahit Kingdom. This is proof that the village community lives together with the bamboo that is still used and has economic benefits until nowdays. Nilai kearifan lokal menjadi kunci bagi keberlanjutan masyarakat lokal yang kehidupannya bergantung pada sumber daya alam yang dimiliki sehingga dapat terindungi. The forest in the Tigawasa village is manages based on local wisdom. They hold the concept of the rule of local knowledge (dresta Bali Aga) by making the forest as a temple Mretiwi (temple without physical building). In the other hands, it become a sacred forest through the implementation of religious ceremonies, such as Sabha Ngubeng, Sabha Mamiut, Sabha Sabuh Baas, Sabha Nyeta and Sabha Malguna. Moreover, the communities developing the myth that the forest sacred local said Tenget and the myth that the forest is a given from God and should be protect by with local customary law of awig-awig of the forest management, (Wijana, 2014).

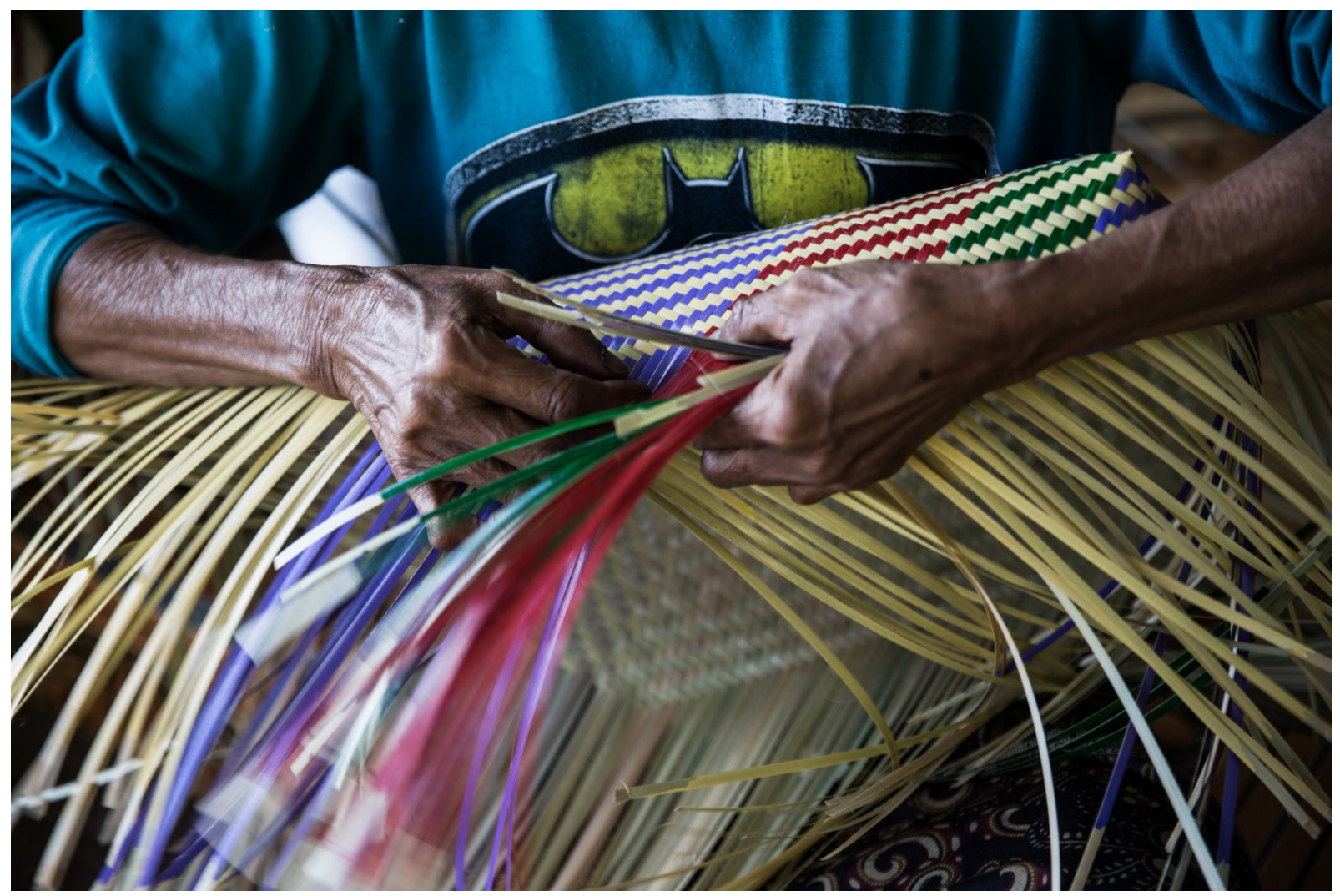

Figure 2. Craftwomen weaves a basket using bamboo sheets. The knowledge is passes down from generation to generation on the Tigawasa Village

Throsby (1995) argues that the most important component that is the core of specific sustainability is the 
responsibility carried by one generation to manage resources by recognizing the needs of future generations. this in the concept of sustainability is intergenerational fairness, namely distributing resources and opportunities between generations between present and future generations. In cultural capital, there is intellectual capital in the form of ideas, practices, beliefs received from the previous generation and passed on to the next generation. Intellectual capital according to Throsby, (1995) must be maintained even though it requires resources, by not it the economic dimension in people's decisions to manage the dimensions of intellectual capital. Soini \& Birkeland (2014) mentioned that in local-based economic development in the context of global development, it is expected to involve and respect local values that exist in society. Moreover, Dorsey et al., (2004) argue that commodification of culture will reduce the rituals and handicrafts for consumption, hiding the social relations that contribute to the production of commodities. Therefore, the efforts by the local community to develop, continue and promote themselves from indigenous knowledge, values, local traditions and customs are also very important by carrying out community-based management, in addition to ecological and economic sustainability which aims to prosper the local community (Grinspoon, 2002; Costa-Neto, 2000).

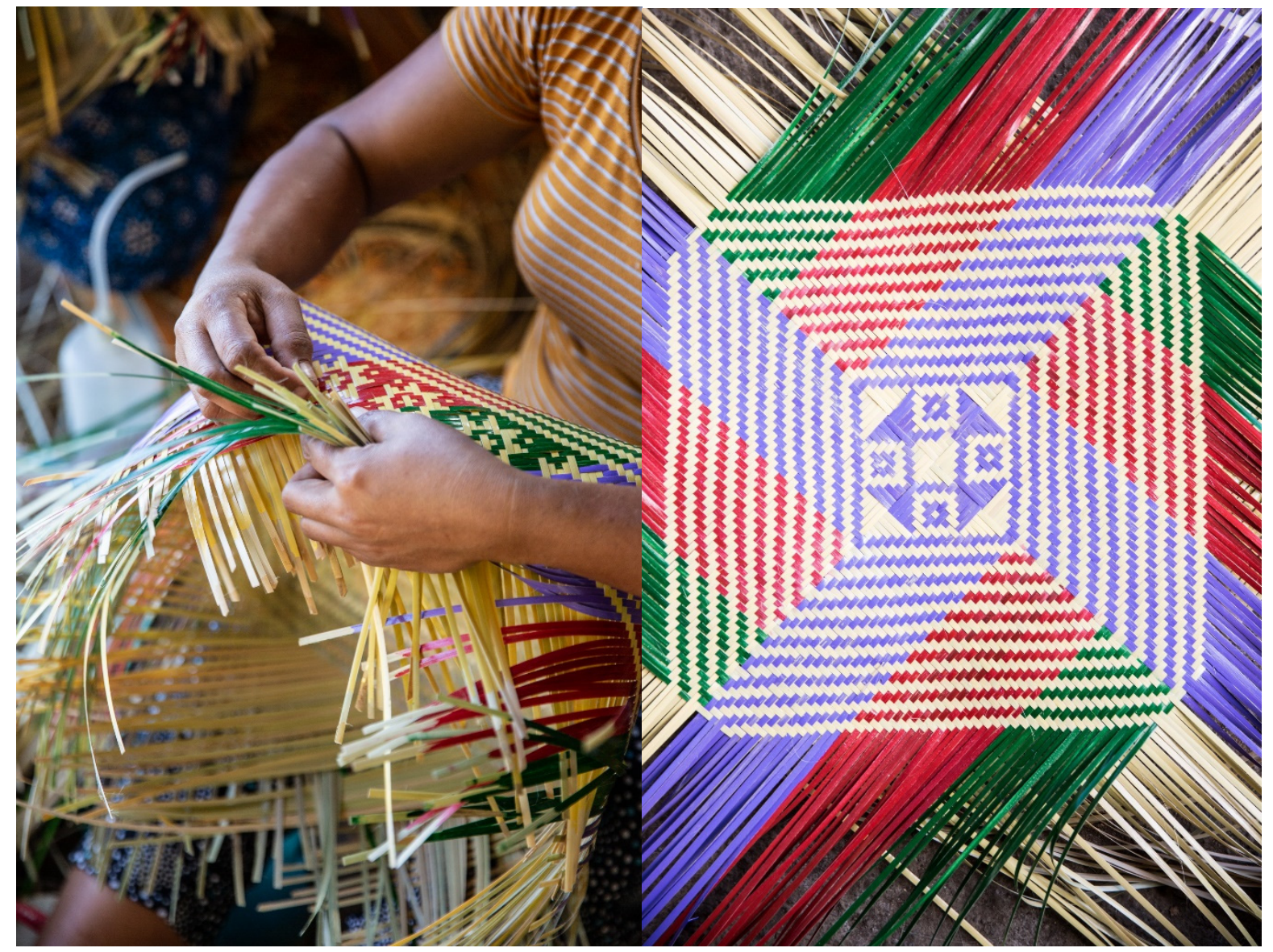

Figure 3. Details of craftswomen weaves a motive of tapuk manggis motives in Umasendi sheets. The tapuk manggis is means a mangosteen leave that fruit's native to island nations of Southeast Asia. Figure 4. Detail of

Tapuk Manggis motive

From that argument, we found the activities of local people who maintain intellectual capital by continuing to the next generation. The regeneration process is also carried out at formal education in the village of Tigawasa. Weaving is teach $t$ in formal education at Elementary School in SD 2 Tigawasa. The process of transfer of knowledge is done by a teacher and also as craftsmen named Putu Suryasa. He has been teaching weaving skills from 2005. In one week, Putu teach weaving of bamboo once on Saturday. In the business profile report of micro, small and medium enterprises and small industries issued by the LPPI and Bank Indonesia in 2015 said, About 60$70 \%$ of MSMEs have not got access or bank financing. Among them are geographic barriers. Not many banks are able to reach up to remote and remote areas. This geographical barrier is experienced by the craftsmen in Tigawasa Village. The location of the village in the mountains is one of the obstacles to access banking. This is reinforced from a testimonial by one of the member local weavers Bamboo Alam group. "craftsmen have significant 
constraints in access to capital as a result of access far enough because the location of the village is located on the mountains. Then administrative constraints to gain access to capital in banking, SMEs business management is still managed manually and traditionally, especially financial management" (Komang Edi, Bambu Alam).

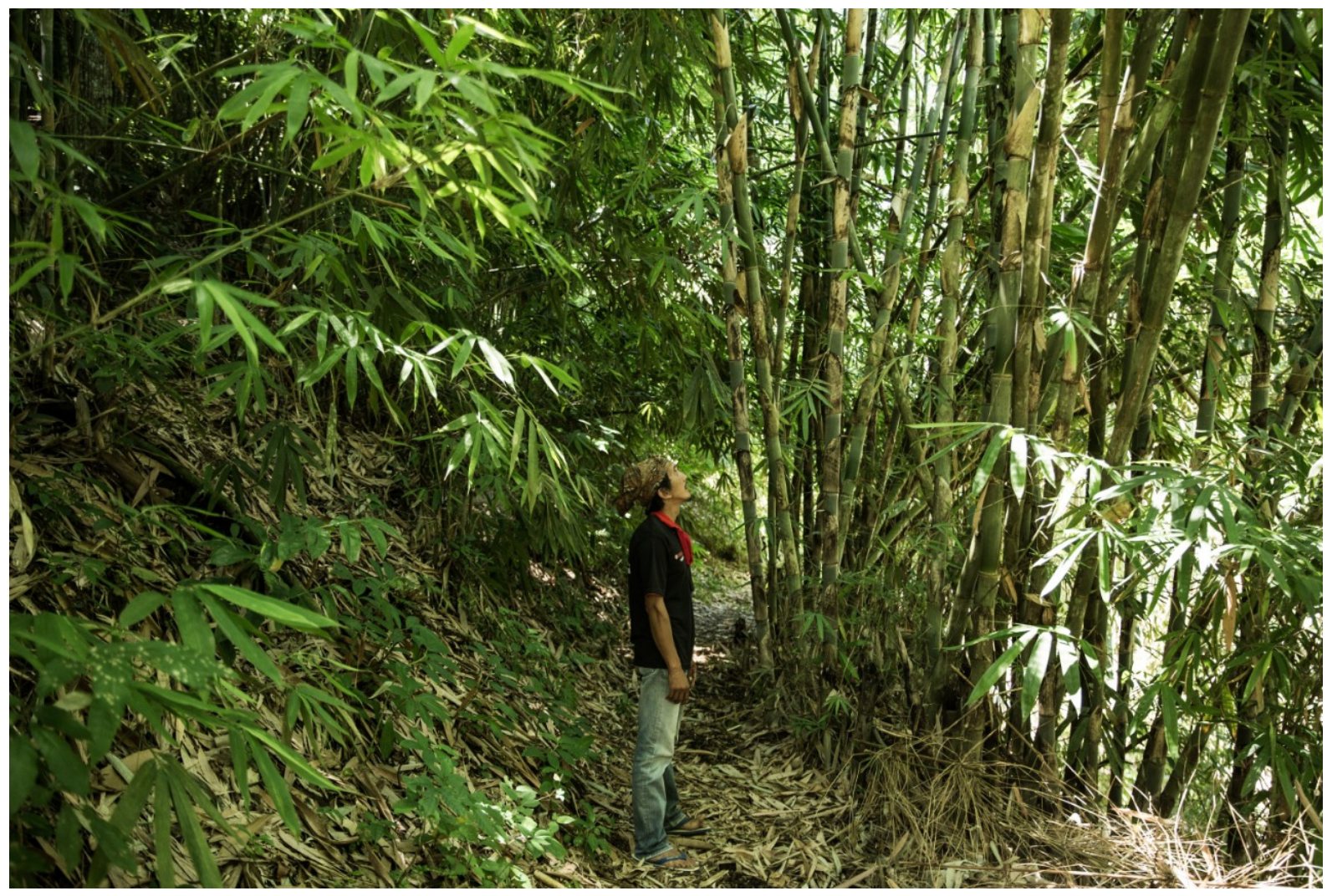

Figure 5. Sanjaya walks on the bamboo forest in Tigawasa Village. socio-cultural life of Tigawasa village community is very united and can not be separated from bamboo and almost all the people who own land, both in the yard and in "tegalan" (garden) planted with bamboo. about 63\% (12 species) bamboo is considered original because it has been owned since the ancestors inhabited this village before the reign of Majapahit Kingdom

In fact, the establishment of microfinance institutions (MFIs) is an appropriate solution to address the problem of credit accessibility experienced by many micro, small and medium enterprises (MSMEs). In Bali there is one form of MFIs namely Lembaga Perkreditan Desa (LPD). LPD is a micro financial institution belonging to the Desa Pekraman (Customary village), the village of the krama, gradually replacing the term desa adat in Bali. Desa Adat is village based on customary law, with three village temples. The desa adat is the owner of the land; the residents are leaseholders. The formation of LPD is based on the cultural heritage of pakraman village which is a form / system of village level government system consisting of family ties (Provinsi, 2002). Another testimonial from the member of Bamboo Alam community in Umasendi Village said that Micro finance institutions have not been maximized in the Village. "the role of micro finance institution that is LPD is actually a solution and hope for the craftsmen to be able to access capital, but not maximal yet. In the village there is BUMDes but the loan interest is too high. Higher than in the Bank" (suyasa, craftman). BUMDes as an abbreviation of a village-owned enterprise is a village business enterprise that is managed by the village government as well as the village community with the aim of strengthening the village economy and is shaped based on the needs and potentials of a village.

Fadhilah Ramadhani, (2013) stated that the barriers that are often encountered by business actors of SME class are capital problem, management of business management, product quality standard, difficulties of market penetration and promotion, difficulties of product distribution, and not yet using proper technology. In the development of bamboo crafts in Tigawasa village, from the previously mentioned barriers, product distribution and marketing strategy are major obstacles in the marketing of goods. According Suyasa, many stock products that accumulate when the collectors do not take products that are ready to be distribute. "We are very dependent on middleman in the City. We do not know where to go, we are dependent on middleman". 


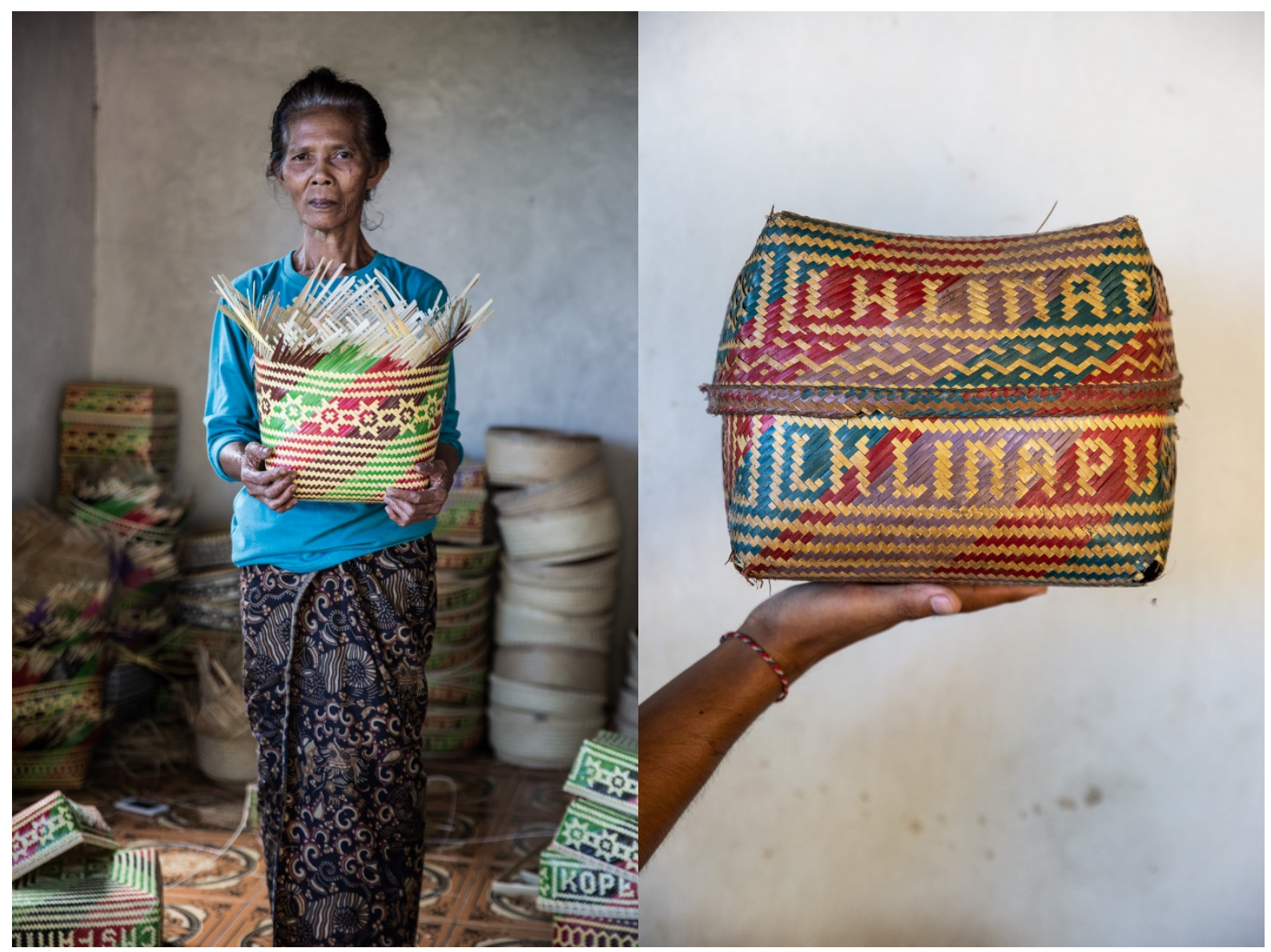

Figure 6. A craftswoman hold unfinished traditional bamboo basket with the nagasari motives. Figure 7. A traditional bamboo basket callen keben with a name of a customer is shown by a worker. The basket is usually use to put an offering which contain of fruits and flower for special accasion for Balinese people during a traditional ceremony 


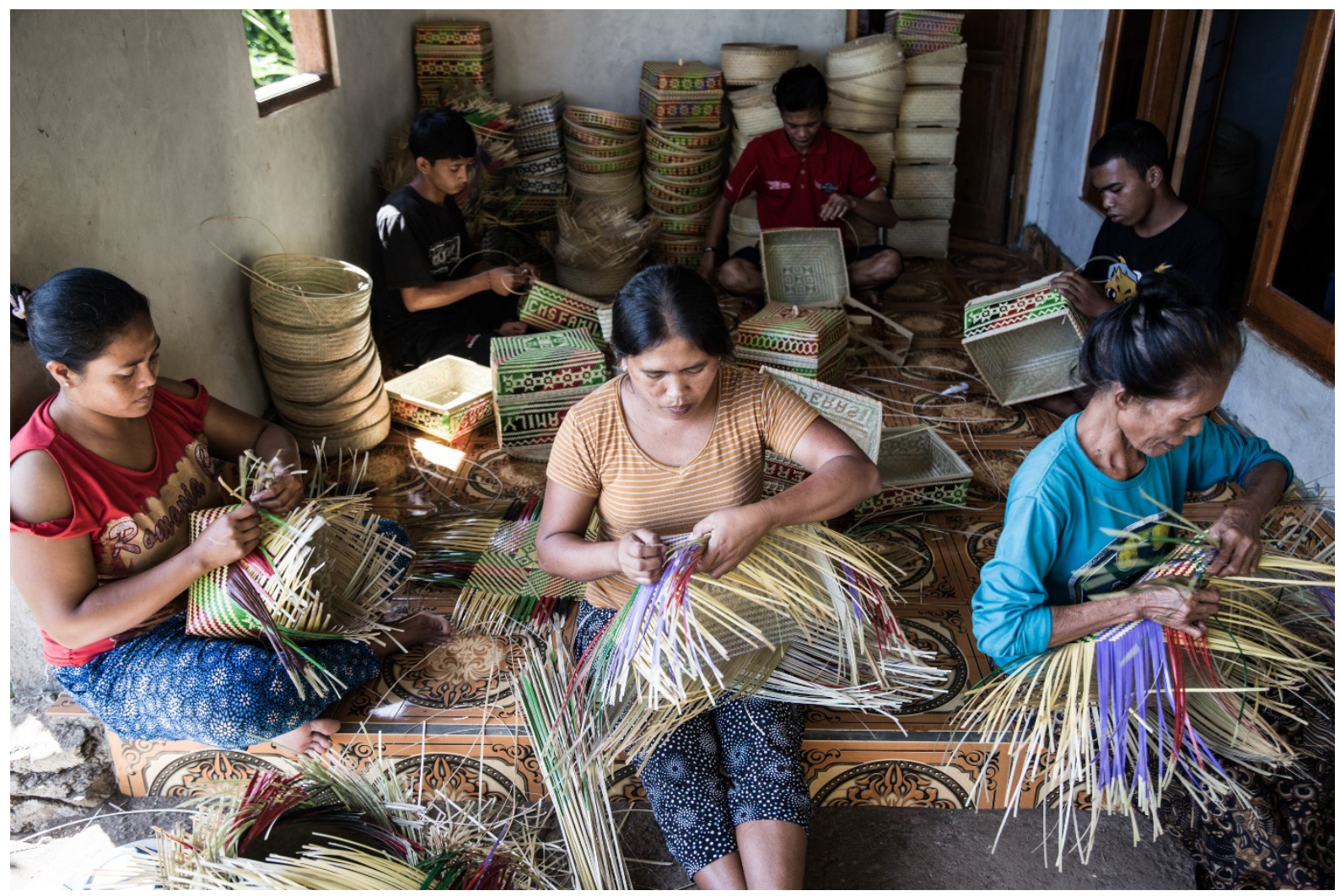

Figure 8. Craftsman and craftswoman weave a basket at Umasendi community

\section{Conclusion}

Global megatrend makes the existence of local communities that depend on their culture and natural resources threatened. The difficult access they get makes their situation more difficult. In fact, the potential is very large where there are local wisdom as a values that actually become strong capital in economic development. The economic activities of a country or region cannot be separated from the local culture. In local culture there is local wisdom which becomes important values in the culture of the community. Every place has its own identity in interpreting local wisdom. This identity and culture is a force in the development of the creative economy. Identity causes knowledge transfer to occur naturally, the surrounding natural resources make a component and creative economy a link so that it can become a policy in creating new jobs, poverty alleviation, welfare, strategies to protect cultural heritage, sustainable development, gender equality. In addition, the creative economy based on local wisdom is strongly associated with the tourism sector, where creative products can be an attraction and economic commodities as a tourist destination. Thus, the relationship between creative industry activities and place identities related to local wisdom is important. However, of course the problem of access to capital needs to be more attention because of the distance between places that are far from urban areas.

\section{Acknowledgement}

This research received research funding from the Ministry of Research, Technology and Higher Education in the Beginner Lecturer Research Scheme 2019.

\section{References}

Arinasa, I. B. K. (2005). Diversity and utilization of bamboo species in Tigawasa Village, Bali. Biodiversitas, Journal of Biological Diversity, 6(1), 17-21. https://doi.org/10.13057/biodiv/d060104

Budarma, I. K., \& Suarta, K. (2017). the Role of Local Value in Global Sustainable Tourism Development Paradigm. the Case of Tourism in Bali. Journal of Business on Hospitality and Tourism, $2(1), 218$. https://doi.org/10.22334/jbhost.v2i1.58

Buitrago, R., Pedro, F., \& Duque Márquez, I. (2012). The Orange Economy. (February), 1-17.

Caves, R. E. (2003). Contracts between Art and Commerce. The Journal of Economic Perspectives, 17(2), 73-84. 
Retrieved from http://www.jstor.org/stable/3216857

Cochrane, P. (2006). Exploring cultural capital and its importance in sustainable development. Ecological Economics, 57(2), 318-330. https://doi.org/10.1016/j.ecolecon.2005.04.012

Duxbury, N., \& Jeannotte, M. S. (2011). Introduction: Culture and Sustainable Communities. Culture and Local Governance, 3(1), 1-10. https://doi.org/10.18192/clg-cgl.v3i1.181

Fahmi, F. Z. (2016). Creative industries and regional economic development in Indonesia: Meanings, patterns and impacts. [Groningen]: University of Groningen.

Gartler, S., Kuklina, V., \& Schweitzer, P. (2020). Culture and sustainability. In Arctic Sustainability, Key Methodologies and Knowledge Domains. https://doi.org/10.4324/9780429277016-3

Gibson, C., \& Kong, L. (2005). Cultural economy: A critical review. Progress in Human Geography, 29(5), 541561. https://doi.org/10.1191/0309132505ph567oa

Harrington, L. M. B. (2016). Sustainability Theory and Conceptual Considerations: A Review of Key Ideas for Sustainability, and the Rural Context. Papers in Applied Geography, 2(4), 365-382. https://doi.org/10.1080/23754931.2016.1239222

Hawkes, J. (2001). The fourth pillar of sustainability: Culture's essential role in public planning. In Common Ground Publishing Pty Ltd in association with the Cultural Development Network (Vic). Retrieved from $\mathrm{http} / / /$ www.culturaldevelopment.net.au/community/Downloads/HawkesJon(2001)TheFourthPillarOfSustain ability.pdf

Hesmondhalgh, D. (2007). The Cultural Industries. Retrieved from https://books.google.com.hk/books?id=SEHTKRXiBL8C

Hesmondhalgh, D. (2008). Cultural and creative industries. The SAGE Handbook of Cultural Analysis, 552-569. https://doi.org/10.4135/9781848608443.n26

Jean-Paul Bourdier, \& Nezar AlSayyad. (1989). Dwellings, settlements, and tradition: cross-cultural perspectives. Lanham : University Press of America; Berkeley, CA : International Association for the Study of Traditional Environments.

Klamer, A. (2017). Doing the Right Thing: A Value Based Economy. London: Ubiquity Press.

Komariah, S. (2016). Local Wisdom of Ciptagelar Community in Managing Environmental Sustainability. 1st UPI International Conference on Sociology Education (UPI ICSE 2015) Local. https://doi.org/10.2991/icse15.2016 .39

Li, S., \& Li, X. (2011). The Role of Cultural Creative Industry in the Process of the City Development: The case $\begin{array}{lllll}\text { of Jingdezhen. Studies in Sociology of } & \text { Science, }\end{array}$ https://doi.org/10.3968/j.sss.1923018420110202.7z0036

Lily Kong, Gibson, C., Khoo, L.-M., \& Semple, A.-L. (2006). Knowledges of the Creative Economy: Towards a Relational Geography of Diffusion and Adaptation in Asia. Asia Pacific Viewpoin, 47(2), 173-194. https://doi.org/10.1111/j.1467-8373.2006.00313.x/abstract

M. Baiquni. (2017). Agenda Kebijakan Pengembangan Wilayah di Era Digital Dan Global. Prosiding Seminar Nasional Geografi UMS 2017 PENGELOLAAN SUMBERDAYA WILAYAH BERKELANJUTAN.

Maha Putra, G. (2017). Defining and Sustaining The Place-Identity of A Traditional Yet Rapidly Developing City. Oxford Brookies University.

Nurse, K. (2006). Culture as the Fourth Pillar of Sustainable Development. Culture, (June), 32-48. Retrieved from http://tcs.sagepub.com/cgi/doi/10.1177/026327690007002004

O'Connor, J. (1998). The cultural production sector in Manchester: research and strategy.

O'Connor, J., \& Xin, G. (2006). A new modernity?: The arrival of "creative industries" in China. International Journal of Cultural Studies, 9(3), 271-283. https://doi.org/10.1177/1367877906066874

Poespowardjo, S. (1986). Understanding Local Genius and Its Relevance in Modernization. In Kepribadian Budaya Bangsa (local genius) (pp. 28-38). pustaka jaya.

Pratt, A. C. (1997). The Cultural Industries Sector: its definition and character from secondary sources on employment and trade, Britain 1984-91. Research Papers in Environmental and Spatial Analysis No 41 (Department of Geography, London School of Economics), (41). 
Pratt, A. C., \& Jeffcutt, P. (2009). Creativity, innovation and the cultural economy. In Creativity, Innovation and the Cultural Economy. https://doi.org/10.4324/9780203880012

Sandoval-Rivera, J. C. A. (2020). Environmental education and indigenous knowledge: Towards the connection of local wisdom with international agendas in the framework of the Sustainable Development Goals (SDGs). $\begin{array}{lllll}\text { Diaspora, Indigenous, } \quad \text { and } & \text { Minority }\end{array}$ https://doi.org/10.1080/15595692.2019.1652588

Scott, A. J. (1999). The cultural economy: Geography and the creative field. Media, Culture and Society, 21(6), 807-817. https://doi.org/10.1177/016344399021006006

Soini, K., \& Birkeland, I. (2014). Exploring the scientific discourse on cultural sustainability. Geoforum, 51, 213223. https://doi.org/10.1016/j.geoforum.2013.12.001

Soini, K., \& Dessein, J. (2016). Culture-sustainability relation: Towards a conceptual framework. Sustainability (Switzerland), 8(2), 13-15. https://doi.org/10.3390/su8020167

Spencer-oatey, H. (2012). What is Culture ? Compiled by. In GlobalPAD Core Concepts.

Suntajaya, I. (2016). Faktor-Fator Yang Mempengaruhi Terjadinya Urbanisasi Di Provinsi Bali. Piramida, 10(2), $61-70$.

Throsby, D. (1995). Culture, economics and sustainability. Journal of Cultural Economics, 19(3), 199-206. https://doi.org/10.1007/BF01074049

Throsby, D. (2001). Economics and culture. In published by the press syndicate of the university of cambridge The Pitt Building, Trumpington Street, Cambridge, United Kingdom. https://doi.org/10.21098/bemp.v22i1.1035

Throsby, D. (2008a). Modelling the cultural industries. International Journal of Cultural Policy, 14(3), 217-232. https://doi.org/10.1080/10286630802281772

Throsby, D. (2008b). The concentric circles model of the cultural industries. Cultural Trends, 17(3), 147-164. https://doi.org/10.1080/09548960802361951

Throsby, D. (2017). Culturally sustainable development: theoretical concept or practical policy instrument? International Journal of Cultural Policy, 23(2), 133-147. https://doi.org/10.1080/10286632.2017.1280788

Throsby, D., \& Petetskaya, E. (2016). Sustainability Concepts in Indigenous and Non-Indigenous Cultures. International Journal of Cultural Property, 23(2), 119-140. https://doi.org/10.1017/S0940739116000084

UNESCO. (2005). Convention on the Protection and Promotion of the Diversity of Cultural Expressions.

UNESCO Statistics. (2009). Measuring the economic contribution of cultural industries: A review and assessment of current methodological approaches. In UNESCO Institute for Statistics.

Wijana, N. (2014). Analisis Komposisi Dan Keanekaragaman Spesies Tumbuhan Di Hutan Desa Bali Aga Tigawasa, Buleleng - Bali. JST (Jurnal Sains Dan Teknologi), 3(1), 288-299. https://doi.org/10.23887/jstundiksha.v3i1.2907

\section{Copyrights}

Copyright for this article is retained by the author(s), with first publication rights granted to the journal.

This is an open-access article distributed under the terms and conditions of the Creative Commons Attribution license (http://creativecommons.org/licenses/by/4.0/). 